\title{
EED wt Allele
}

National Cancer Institute

\section{Source}

National Cancer Institute. EED wt Allele. NCI Thesaurus. Code C101723.

Human EED wild-type allele is located within 11q14.2-q22.3 and is approximately $34 \mathrm{~kb}$ in length. This allele, which encodes polycomb protein EED, is involved in both histone methylation and transcriptional regulation. 